\title{
Fecal carriage of multiresistant bacteria versus infection in ICU wards patients
}

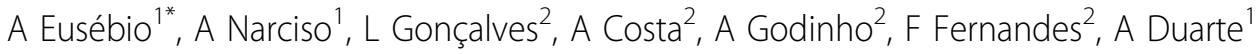 \\ From International Conference on Prevention \& Infection Control (ICPIC 2011) \\ Geneva, Switzerland. 29 June - 2 July 2011
}

\section{Introduction / objectives}

Healthcare-associated infections (HAI) constitute major health care problem from their frequency, cost and gravity. Fecal carriage of extended-spectrum beta-lactamase (ESBL)-producing isolates has mainly been detected in HAI, and few studies have evaluated fecal carriage during non-outbreak situations and among patients in the community. This study was undertaken to determine the spectrum of bacterial colonization and predisposing risk factors in patients being admitted to an acute care hospital, Lisboa, with special emphasis on ESBL producing Gram-negative bacteria.

\section{Methods}

To decrease HAI some active preventive measures were taken since November to February 2010. Nasal, oral and rectal swab samples were collected and processed for isolation of ESBL on chromID ESBL (bioMerieux).

\section{Results}

Bacterial colonization of one or more sites on admission was detected in 37 patients included in the study. The most common colonizers were Escherichia coli $(\mathrm{n}=10)$; PseudomonasÂ aeruginosa $(\mathrm{n}=9)$; Klebsiella pneumoniae $(\mathrm{n}=8)$ and Enterobacter cloacae $(\mathrm{n}=7)$, with simultaneous colonization in six patients. Seven patients were colonized and infected (blood, urine and bronchial secretion) with the same specie identified from rectal swab. After one month of admission at ICU two inpatients were infected (catheter and pus) with P. aeruginosa and Stenotrophomonas maltophilia present at admission in hospital.

\section{Conclusion}

This study alerts $\hat{A}$ medical professionals that should be aware of these isolates, should continue strict hygiene

${ }^{1}$ i.Med, Faculdade de Farmàcia, Lisbon, Portugal

Full list of author information is available at the end of the article procedures and, additionally, should implement an ESBL screening system, in particular for faecal carriage, in order to prevent possible outbreaks caused by these multi-resistant organisms.

\section{Disclosure of interest}

None declared.

\section{Author details}

${ }^{1}$ i.Med, Faculdade de Farmàcia, Lisbon, Portugal. ${ }^{2}$ SAMS Hospital, Lisbon, Portugal.

Published: 29 June 2011

doi:10.1186/1753-6561-5-S6-P134

Cite this article as: Eusébio et al:: Fecal carriage of multiresistant

bacteria versus infection in ICU wards patients. BMC Proceedings 20115 (Suppl 6):P134.
Submit your next manuscript to BioMed Central and take full advantage of:

- Convenient online submission

- Thorough peer review

- No space constraints or color figure charges

- Immediate publication on acceptance

- Inclusion in PubMed, CAS, Scopus and Google Scholar

- Research which is freely available for redistribution
C Biomed Central

\section{Biomed Central}

(c) 2011 Eusébio et al; licensee BioMed Central Ltd. This is an open access article distributed under the terms of the Creative Commons Attribution License (http://creativecommons.org/licenses/by/2.0), which permits unrestricted use, distribution, and reproduction in any medium, provided the original work is properly cited. 